\title{
Endogeneity of the elasticities and the real exchange rate in a balance of payments constrained growth model: cross-country empirical evidence ${ }^{*}$
}

\author{
Renato S. Campos ${ }^{\dagger}$ \\ Frederico G. Jayme Jr." \\ Gustavo Britto
}

\begin{abstract}
Balance of payments constrained growth models are notable for their longevity. This is especially true for the case of Thirlwall's Law, which defines that a country's sustainable growth rate is given by the ratio between the income elasticity of exports and that of imports. In light of this, the current paper explores the hypothesis that the income elasticities of this type of models are endogenous. The debate on the latter is resurgent in the literature. The results provide evidence that the ratio is, indeed, exogenous, and that the level of the real exchange rate influences economic growth as it determines such ratio. In other words, the real exchange rate is important for improving non-price competitiveness without, however, making the ratio between elasticities endogenous.
\end{abstract}

Keywords: Thirwall's Law; income elasticity; real exchange rate.

JEL Classification: 011; 014; 019.

\footnotetext{
${ }^{* *}$ We would like to thank Peter Phelps, Effie Kasidou, and Gary Dimsky, from Leeds Business School, and Pedro Loureiro, from Cambridge University, for helpful comments in an earlier version of this paper. The usual disclaimers apply.

† Department of Business and Economics, Universidade Federal de Lavras. Email: renato.campos@dae.ufla.br

*Cedeplar, Universidade Federal de Minas Gerais. Email: gonzaga@cedeplar.ufmg.br

\Cedeplar, Universidade Federal de Minas Gerais. Email: gustavo@cedeplar.ufmg.br
} 


\section{Introduction}

Thirlwall's (1979) seminal paper suggests that a country's maximum sustainable growth rate is given by the equation that defines the growth rate compatible with balance of payments equilibrium. Its equation is $y_{B P}=x / \pi=$ $\varepsilon z / \pi$, where $x$ is the growth rate of exports, $\pi$ is the income elasticity of the demand for imports, $\varepsilon$ is the income elasticity of the demand for exports and $z$ is the growth rate of world income. This relationship came to be known as Thirlwall's Law.

As McCombie (2011) puts it, the rationality behind this "law" is that no country can grow faster than compatible with balance of payments equilibrium for long periods of time or its foreign debt, as a proportion of GDP, would rise to such a level that would cause international confidence to plummet, a decrease in the capacity of acquiring foreign credit and a currency crisis. On the other hand, if the balance of payments equilibrium growth rate is lower than factor endowments would otherwise allow, the country is constrained to grow at a lower speed.

Through time, objections to Thirlwall's hypotheses have arisen (for example, Blecker, 2016; Cortes e Bosch, 2015). It is true that the existing studies, both for developed and for emerging countries, suggest that "Thirlwall's Law" cannot be rejected - or, yet, that there might be differences between the income elasticities of countries. This notwithstanding, few works suggest an endogenous relationship between the ratio of income elasticities and relative growth rates. The importance of the real exchange rate for the balance of payments constraint and for economic growth is another neglected issue.

This work intends to empirically asses the hypothesis that the elasticities of the balance of payments constrained growth model are endogenous. It furthermore intends to identify the level of the real exchange rate as one of the elements that explain growth, particularly for developing countries. In all effect, the works based on Thirlwall's (1979) model assume the hypothesis that, in the long-term, relative prices either remain unchanged or have a negligible impact. There is, on the other hand, an emerging literature that highlights the influence of the exchange rate on growth, both directly (see, for example, Rodrik, 2008; Gala, 2007; Sampaio and Gala, 2008) and indirectly - in this case, as it determines the income elasticities (as in Missio and Jayme Jr., 2012). 
Besides this introduction and the conclusions, this article is divided into three more sections. The following one discusses export-led growth models and the relevant theoretical issues. Section 3 in turn presents the model and the data we used, while the fourth one empirically analyses the relationship between the endogeneity of the elasticities and the role of the real exchange rate.

\section{Growth-led models and endogenous elasticities}

Thirlwall (2002, p. 52) notes that "in neoclassical theory, output growth is a function of factor inputs and factor productivity with no recognition that factor inputs are endogenous, and that factor productivity growth may also be a function of the pressure of demand in an economy. In practice, labour is a derived demand, derived from the demand for output itself. Capital is a produced means of production and it is therefore as much a consequence of the growth of output as its cause. Factor productivity growth will be endogenous if there are static and dynamic returns to scale."

Thirlwall's first model shows basically that the export demand function is the most important component of autonomous demand in an open economy. The growth of exports thus governs the long-term growth of output, with the other components of demand adapting to it. It is thus assumed that

$$
g_{t}=\gamma\left(x_{t}\right)
$$

where $g_{t}$ is the growth rate of output over time, which is function of $x_{t}$, the growth rate of exports. The export demand function is straightforward

$$
X_{t}=A\left(P_{d t} / P_{f t}\right)^{\eta} Z_{t}^{\varepsilon}
$$

which, expressed as rates of change, becomes

$$
x_{t}=\eta\left(P_{d t} / P_{f t}\right)+\varepsilon\left(z_{t}\right)
$$

where $P_{d}$ are domestic prices, $P_{f}$ are the prices of competitors measured in a common currency, $Z$ is income outside the country, $\eta(<0)$ is the price elasticity of the demand for exports and $\varepsilon(>0)$ is the income elasticity of the demand for exports.

The growth of the income of the rest of the world and foreign prices can be considered exogenous, but the rise of domestic prices can be considered 
endogenous. It is derived from a mark-up pricing equation in which prices are based on unit labour costs and a mark-up rate

$$
P_{d t}=\left(W_{t} / R_{t}\right)\left(T_{t}\right)
$$

where $W$ is the national wage rate, $R$ is the average output of labour and $T$ is $1+$ the mark-up on unit labour costs. In rates of change,

$$
p_{d t}=\omega_{t}-r_{t}+\tau_{t}
$$

Productivity gains, in turn, partly depend on the growth of output itself. This is due to static and dynamic returns to scale, as given by Verdoorn's Law

$$
r_{t}=r_{a t}+\lambda\left(g_{t}\right)
$$

where $r_{a t}$ is the autonomous growth of productivity and $\lambda$ is Verdoorn's coefficient. Verdoorn's relation establishes the possibility of a virtuous growth cycle, led by demand.

The model's equilibrium solution is reached through the following procedure: (6) is substituted into (5), the latter's results into (3) and, finally, this is substituted into (1). The result is

$$
g_{t}=\gamma \frac{\left[\eta\left(\omega-r_{a t}+\tau_{t}-p_{f t}\right)+\varepsilon\left(z_{t}\right)\right]}{1+\gamma \eta \lambda}
$$

The Verdoorn coefficient $(\lambda)$ enlarges growth rate differences between economies arising from differences in other parameters and variables (which means that the higher is $\lambda$, the smaller will be the denominator, since $\eta<0$ ). If $\lambda=0$, the differences are not increased.

If model (7) is seen merely as an export-led model, without any Verdoorn effect feedback and with constant prices, equation (7) reduces to

$$
g_{t}=\gamma \varepsilon\left(z_{t}\right)
$$

By imposing a balance of payments constraint, one obtains $\gamma=1 / \pi$, where $\pi$ is the income elasticity of the demand for imports. Thus,

$$
g_{t}=\varepsilon\left(z_{t}\right) / \pi \quad \text { or } \quad g_{t} / z_{t}=\varepsilon / \pi .
$$


This result shows that the growth rate of a country relative to all the others $(z)$ is equiproportional to the ratio of the income elasticities of the demand for exports and imports - as Thirlwall (1979) has shown.

Based on a similar construction, Krugman (1989) proposed inverting the causality of the models above. In his model, the growth of the labour force determines the growth of output, and the rapid increase of the latter leads to fastgrowing exports - hence the apparently higher income elasticity of the demand for exports. Causality runs, in contradistinction to Kaldorian-inspired models, from growth to the export elasticities, and not from the latter to the former. It is thus the case that the income elasticities, according to this approach, are not structural parameters, but rather variables that adjust to reach equilibrium with the ratio between the growth rates of national and world income. In other words, Krugman makes the elasticities endogenous.

As McCombie and Thirlwall (1994) also do, Krugman (1989) rejected the hypothesis that changes of the real exchange rate are an important component for keeping balance of payments equilibrium. Since prices do not adjust - for output changes in response to variations of the real exchange rate - and assuming income gaps are differences in factor endowments and productivity, the author concludes that the elasticities should adjust to income variations ${ }^{1}$. According to him, the explanation is that different growth rates impact trade flows in a manner that creates differences in the apparent elasticity. Elasticity is apparent, in turn, because countries do not in effect face the demand curve, but rather the demand curve supply variations bring about (Carvalho, 2007).

McCombie (2011) considers Krugman's paper important because it discusses precisely the direction of causality. Taking into account the New Trade Theory, the monopolistic competition arising therefrom and increasing returns to scale, Krugman argued that faster growth leads to higher specialisation and the production of new goods to be sold in the world market. Therefore, high income elasticities of the demand for exports depend on supply-side dynamics and on fast growth, not the other way around.

McCombie (2011) argued that there are three problems with Krugman's explanation. First, the degree of specialisation and the capacity of profiting from it are, at least partially, a function of the size of the economy. Second, there are many

\footnotetext{
${ }^{1}$ Thirlwall called this the 45-degrees rule. Cf. McCombie and Thirlwall (1994).
} 
ways slow output growth can lead to a slow growth of total factor productivity. Indeed, there are a rich literature on growth models, such the export led growth using the Hicks super multiplier, the cumulative causation (Myrdal, 1957), Schumpeterian models induced investment by technical progress, learning by doing, economies of scale among others. Verdoorn's Law supplies substantial evidence on the importance of these elements (McCombie and Thirlwall, 1994; McCombie et al., 2002). Finally, the third problem is that, for a developing country, it is rather unlikely that specialising in a commodity will increase its income elasticity of the demand for exports.

Thirlwall (2002) considers that Krugman's reversed causality hypothesis is a tautology. In Thirlwall's (1979) model, wherein causality runs from the elasticities to growth, the former reflects the structure of production. This is the basic assumption of all classic centre-periphery models. Even amongst industrialised countries (Krugman's main focus), feedback mechanisms as the ones already described (associated to Verdoorn's Law) tend to perpetuate initial differences in income elasticities associated, on the one hand, to "inferior" industrial structures, and, on the other, to "superior" ones (Thirlwall, 2005).

In models inspired by Thirlwall (1979), the "lack of structure" of the elasticities many times involves, as in Krugman's (1989) approach, the question of the extent to which income elasticities can be taken as exogenous (as the original models in line with Thirlwall's suggest) or endogenous (as Krugman suggests).

Based on Thirlwall's original approach, authors such as McCombie and Roberts (2002) and Missio and Jayme Jr. (2012) propose "solutions" for making the income elasticities endogenous without, however, inverting the direction of causality. These authors maintain the premise that a country's sustainable growth rate is given by the product of the ratio of its income elasticities and the growth rate of world income, without the need of assuming that these elasticities are exogenous.

It should not be forgotten that, in many instances, the income elasticities of the countries are largely determined by natural resource endowments and the characteristics of the goods they produce. These are products of history, which are independent of the growth of output. An obvious example is the contrast between primary product production and industrial production: primary products tend to have an income elasticity of demand less than unity (Engel's Law), while most industrial products have an income elasticity greater than unity (Thirlwall, 2005). 
In this vein, a slightly different way of making the elasticities endogenous, which furthermore allows for a structural analysis of their changes, is expanding Thirlwall's model to a multi-sector approach. By doing so, the sectoral composition of the country's structure of production and its specialisation pattern makes aggregate elasticities endogenous (Silveira, 2011). This is what Araújo and Lima (2007) intend with their model.

McCombie and Roberts (2002), in turn, propose a balance of payments constraint model with hysteresis in the elasticities. Specifically, the income elasticities of the demand are a non-linear function of past growth rates (a sufficient condition to break with the equilibrium conditions of the standard model).

Missio and Jayme Jr. (2012) explore the relationship between the exchange rate, structural heterogeneity and the income elasticities of the demand for exports and imports in developing economies. Their goal is to test whether a competitive real exchange rate leads to a diversification of the investment and the production of sectors that operate in the world market. The authors indicate that real exchange rate undervaluation affects an economy's productive heterogeneity. The elasticities are endogenous in the authors' model through the level of the real exchange rate. If the latter is depreciated, this might foster research and development, given its positive impact on self-financing conditions and access to credit, thus making it possible to modernise and diversify the structure of production. In the long-term, this leads to higher export capacity and reduced dependence on imports.

Most recently Missio et al. (2017) extend the model developed by Araujo and Lima (2007) to derive a balance-of-payments equilibrium growth rate analogous to Thirlwall's Law based on a Pasinettian multi-sector macrodynamic framework in which income elasticities are endogenous to the level of the real exchange. Furthermore, the model was built to relate growth, the real exchange rate and sectoral heterogeneity. From a cumulative causation perspective, the authors demonstrate the effect of the level of real exchange rates on the generation of technological progress, and how these rates also impact the growth of the whole economy via a balance-of-payments constrained approach. The authors show that an undervalued real exchange rate has positive effects on economic growth in developing countries. 


\section{Testing the hypothesis of endogenous elasticities and the role of the real exchange rate}

\subsection{Data sources}

In order to analyse the hypothesis that the ratio of the income elasticities is endogenous, as well as the importance of the exchange rate, we must estimate income elasticities for a series of countries. We used the annual volume of exports and imports and world and domestic income. The dataset is the World Development Indicators (World Bank), and they are listed in Table $1^{2}$.

To find the real exchange rate we take the World Development Indicators (World Bank). We used the Consumer Price Index (CPI) for the countries listed in table 1, with the United States as the basis for all foreign price levels and 2005 as the base-year. Besides the CPI, we also collected time series of the nominal exchange rate, in local currency units per U.S. dollars. To study the endogeneity of elasticities (instrumental variables) we employ the average real exchange rate of the last 10 years for which there is data.

To look into the endogeneity of the ratio of the income elasticities we used another variable (as an instrument) to perform the Durbin-Wu-Hausman (DWH) endogeneity test. This other variable is the share of technology-intensive sectors in a country's total exports. We estimated the "share of technology-intensive sectors in total exports" using the methodology Lall (2001) proposes. The author classifies output into primary products (PP), resource-based manufactures (RB), low technology manufactures (LT), medium technology manufactures (MT) and high technology manufactures (HT). Based on this classification, we can group MT and HT manufactures into a high technology sector (HT) and RB and LT manufactures into a low technology one (LT), leaving primary products in a category of their own.

We thus took the share of the high technology sector $(\mathrm{MT}+\mathrm{HT})$ in total exports as the instrument for the ratio of elasticities, in order to estimate the instrumental variables models. We define this variable as the average value of seven years of variations (2004 to 2010).

\footnotetext{
${ }^{2}$ We follow Blecker and Razmi (2007) to select the countries used in this study. For more information on country selection, see the Appendix.
} 
The share of the different sectors in a country's total exports, according to Lall's (2011) classification, can be found at the website of the Economic Commission for Latin America and the Caribbean, in the Interactive Graphic System of International Economics Trends section (IGSIET).

\subsection{Aggregate estimation of the elasticities of foreign trade}

In order to test the hypothesis that the ratio of the elasticities is endogenous, we employ the Durbin-Wu-Hausman (DWH) endogeneity test. It tests for endogeneity in a model estimated by instrumental variables. Besides, we use the Instrumental Variables to test this hypothesis, based on Cameron and Trivedi (2009). The instrumental variables estimator (IV) is consistent under the assumption of valid instruments $(\mathrm{z})$. The latter are variables correlated to the regressor $\mathrm{x}$, which satisfy $E(u \mid Z)=0$. The IV approach is the original and most widely used method to estimate the parameters of models with endogenous regressors.

Our research strategy is as follows. We first estimate the ratio of income elasticities of the demand for exports and imports for 38 countries. Given this, we then run a cross-country regression of the average relative growth rate of output against the previously estimated ratio.

Considering Thirlwall's Law equilibrium equation, from the former section, we obtain the following testable model

$$
\left(\frac{y}{z}\right)_{i}=\beta\left(\frac{\varepsilon_{i}}{\pi_{i}}\right)+u_{i}
$$

Where $y_{i} / z$ is the ratio between national income and world income and $\varepsilon_{i} / \pi_{i}$ is the ratio of the income elasticities of the demand for exports and imports. On the one hand, for the simplest version of Thilrwall's Law in equation (10) to be valid, $\beta$ must equal 1 . On the other hand, for the endogeneity hypothesis to be valid, $\varepsilon_{i} / \pi_{i}$ must be endogenous in this equation.

To obtain these estimates we used the error correction term (ECT), since it contributes to the parameterization of a Vector Error Correction (VEC) equation. However, the VEC parameterization was not possible for all countries, given that some residuals were auto-correlated, heteroskedastic and non-normally distributed. For these cases, we estimated the parameter using an autoregressive distributed lag model (ADL). This model, besides breaking with the hypothesis of 
endogenous variables, allows other parameterizations that can adjust for the problems of the residuals (in some cases). Table 1 displays the estimates of the income elasticities for several countries. The numbers in bold were estimated by the vector error correction model, while those not in bold were estimated by the ADL model.

Table 1. Estimation of the elasticities

\begin{tabular}{|c|c|c|c|c|c|c|c|c|}
\hline \multirow[b]{2}{*}{ País } & \multirow[b]{2}{*}{ Período } & \multicolumn{2}{|c|}{$\begin{array}{c}\text { Elasticidades } \\
\text { [estatística t] }\end{array}$} & \multirow{2}{*}{$\begin{array}{l}\text { Razão } \\
(\varepsilon / \pi)\end{array}$} & \multirow{2}{*}{$\begin{array}{c}\text { PIBML } \\
\text { (z) }\end{array}$} & \multirow{2}{*}{$\begin{array}{c}\text { BPCG } \\
(\varepsilon / \pi) \times z\end{array}$} & \multirow{2}{*}{$\begin{array}{l}\text { PIB } \\
(y)\end{array}$} & \multirow{2}{*}{$\begin{array}{c}\text { PIB/PIBML } \\
(y / z)\end{array}$} \\
\hline & & $\begin{array}{c}\text { Export. } \\
(\varepsilon)\end{array}$ & $\begin{array}{c}\text { Import. } \\
\text { ( } \pi)\end{array}$ & & & & & \\
\hline Argentina & $\begin{array}{l}1962- \\
2011\end{array}$ & $\begin{array}{c}2,2379^{*} \\
{[16,8]}\end{array}$ & $\begin{array}{l}2,503^{*} \\
{[11,1]}\end{array}$ & 0,8941 & 3,4548 & 3,0889 & 2,842 & 0,8226 \\
\hline Austrália & $\begin{array}{l}1960- \\
2011\end{array}$ & $\begin{array}{c}1,5701^{*} \\
{[16,4]}\end{array}$ & $\begin{array}{c}2,0274^{*} \\
{[10,4]}\end{array}$ & 0,7744 & 3,471 & 2,6881 & 3,4938 & 1,0066 \\
\hline Bélgica & $\begin{array}{l}1960- \\
2010\end{array}$ & $\begin{array}{c}1,4433^{*} \\
{[10,4]}\end{array}$ & $\begin{array}{c}1,7918^{*} \\
{[9,6]}\end{array}$ & 0,8055 & 3,4869 & 2,8087 & 2,7296 & 0,7828 \\
\hline Brasil & $\begin{array}{l}1980- \\
2011\end{array}$ & $\begin{array}{c}2,2326^{*} \\
{[43,2]}\end{array}$ & $\begin{array}{c}2,2853^{*} \\
{[9,3]}\end{array}$ & 0,9769 & 2,7929 & 2,7285 & 2,7291 & 0,9771 \\
\hline Camarões & $\begin{array}{l}1968- \\
2011\end{array}$ & $\begin{array}{c}4,1951^{*} \\
{[2,6]}\end{array}$ & $\begin{array}{c}3,8381^{*} \\
{[3,3]}\end{array}$ & 1,093 & 3,1754 & 3,4707 & 3,6356 & 1,1449 \\
\hline Canadá & $\begin{array}{l}1960- \\
2010\end{array}$ & $\begin{array}{c}1,5221^{*} \\
{[13,3]}\end{array}$ & $\begin{array}{c}1,8878^{*} \\
{[9,97]}\end{array}$ & 0,8063 & 3,4869 & 2,8114 & 3,2967 & 0,9454 \\
\hline Chile & $\begin{array}{l}1970- \\
2011\end{array}$ & $\begin{array}{c}2,4445^{*} \\
{[9,8]}\end{array}$ & $\begin{array}{c}1,5368^{*} \\
{[11,4]}\end{array}$ & 1,5906 & 3,0402 & 4,8359 & 4,1227 & 1,356 \\
\hline China & $\begin{array}{l}1986- \\
2011\end{array}$ & $\begin{array}{c}6,0254^{*} \\
{[27,4]}\end{array}$ & $\begin{array}{c}1,862^{*} \\
{[9,2]}\end{array}$ & 3,236 & 2,8325 & 9,1658 & 9,4374 & 3,3319 \\
\hline Colômbia & $\begin{array}{l}1960- \\
2010\end{array}$ & $\begin{array}{c}1,5517^{*} \\
{[8,2]}\end{array}$ & $\begin{array}{c}1,4992^{*} \\
{[4,2]} \\
\end{array}$ & 1,035 & 3,4869 & 3,609 & 4,1264 & 1,1834 \\
\hline $\begin{array}{l}\text { Costa do } \\
\text { Marfim }\end{array}$ & $\begin{array}{l}1960- \\
2011\end{array}$ & $\begin{array}{c}1,2367^{*} \\
{[8,9]}\end{array}$ & $\begin{array}{c}1,3441^{*} \\
{[5,7]}\end{array}$ & 0,9201 & 3,471 & 3,1937 & 3,3494 & 0,965 \\
\hline $\begin{array}{l}\text { Republica } \\
\text { Dominicana }\end{array}$ & $\begin{array}{l}1960- \\
2011\end{array}$ & $\begin{array}{c}1,5594^{*} \\
{[8,4]}\end{array}$ & $\begin{array}{c}0,9055^{*} \\
{[20,0]}\end{array}$ & 1,7221 & 3,471 & 5,9776 & 5,162 & 1,4872 \\
\hline Equador & $\begin{array}{l}1960- \\
2010\end{array}$ & $\begin{array}{l}2,0555^{*} \\
{[17,98]}\end{array}$ & $\begin{array}{c}1,4656^{*} \\
{[10,8]}\end{array}$ & 1,4025 & 3,4869 & 4,8904 & 3,8526 & 1,1049 \\
\hline França & $\begin{array}{l}1960- \\
2010\end{array}$ & $\begin{array}{c}2,0752^{*} \\
{[6,3]}\end{array}$ & $\begin{array}{c}2,00728^{*} \\
{[34,9]}\end{array}$ & 1,0338 & 3,4869 & 3,6049 & 2,8863 & 0,8278 \\
\hline Alemanha & $\begin{array}{l}1970- \\
2010\end{array}$ & $\begin{array}{c}1,5809^{*} \\
{[26,9]}\end{array}$ & $\begin{array}{c}1,9788^{*} \\
{[23,3]}\end{array}$ & 0,7989 & 3,0491 & 2,436 & 2 & 0,6559 \\
\hline Hong Kong & $\begin{array}{l}1981- \\
2010\end{array}$ & $\begin{array}{c}2,7504^{*} \\
{[7,65]} \\
\end{array}$ & $\begin{array}{c}1,98^{*} \\
{[34,0]} \\
\end{array}$ & 1,3891 & 2,8288 & 3,9294 & 4,7643 & 1,6842 \\
\hline Índia & $\begin{array}{l}1960- \\
2011\end{array}$ & $\begin{array}{c}4,8035^{*} \\
{[6,3]}\end{array}$ & $\begin{array}{c}3,1494^{*} \\
{[3,4]}\end{array}$ & 1,5252 & 3,471 & 5,294 & 5,004 & 1,4417 \\
\hline
\end{tabular}


Table 1. Estimation of the elasticities (Continued)

\begin{tabular}{|c|c|c|c|c|c|c|c|c|}
\hline Indonésia & $\begin{array}{l}1967- \\
2011\end{array}$ & $\begin{array}{c}2,7768^{*} \\
{[7,4]}\end{array}$ & $\begin{array}{l}1,439^{*} \\
{[16,3]}\end{array}$ & 1,9297 & 3,2039 & 6,1825 & 5,859 & 1,8287 \\
\hline Itália & $\begin{array}{l}1960- \\
2010\end{array}$ & $\begin{array}{c}1,7213^{*} \\
{[14,3]}\end{array}$ & $\begin{array}{c}2,2386^{*} \\
{[3,7]}\end{array}$ & 0,7689 & 3,4869 & 2,6812 & 2,7236 & 0,7811 \\
\hline Japão & $\begin{array}{l}1960- \\
2010\end{array}$ & $\begin{array}{c}1,1852^{*} \\
{[3,4]}\end{array}$ & $\begin{array}{c}1,1319^{*} \\
{[3,97]}\end{array}$ & 1,0471 & 3,4869 & 3,6511 & 3,9156 & 1,1229 \\
\hline $\begin{array}{l}\text { Coréia do } \\
\text { Sul }\end{array}$ & $\begin{array}{l}1966- \\
2010\end{array}$ & $\begin{array}{c}3,3855^{*} \\
{[17,6]}\end{array}$ & $\begin{array}{c}1,3492^{*} \\
{[19,2]}\end{array}$ & 2,5093 & 3,2755 & 8,2191 & 6,7434 & 2,0587 \\
\hline Malásia & $\begin{array}{c}1960- \\
2010\end{array}$ & $\begin{array}{c}3,4398^{*} \\
{[3,2]}\end{array}$ & $\begin{array}{c}1,4453^{*} \\
{[10,9]}\end{array}$ & 2,38 & 3,4869 & 8,2988 & 6,2008 & 1,7783 \\
\hline Mauritius & $\begin{array}{l}1976- \\
2011\end{array}$ & $\begin{array}{c}1,353^{* *} \\
{[2,45]}\end{array}$ & $\begin{array}{c}0,8602^{*} \\
{[10,3]}\end{array}$ & 1,5729 & 2,9655 & 4,6644 & 4,4118 & 1,4877 \\
\hline México & $\begin{array}{l}1960- \\
2011\end{array}$ & $\begin{array}{c}2,9336^{*} \\
{[13,4]}\end{array}$ & $\begin{array}{c}2,3239^{*} \\
{[3,48]}\end{array}$ & 1,2624 & 3,471 & 4,3817 & 3,984 & 1,1478 \\
\hline Holanda & $\begin{array}{l}1960- \\
2010\end{array}$ & $\begin{array}{c}1,5549^{*} \\
{[12,2]}\end{array}$ & $\begin{array}{c}1,9507^{*} \\
{[15,8]}\end{array}$ & 0,7971 & 3,4869 & 2,7794 & 3,0017 & 0,8608 \\
\hline Paquistão & $\begin{array}{l}1960- \\
2011\end{array}$ & $\begin{array}{c}4,5401^{*} \\
{[4,6]}\end{array}$ & $\begin{array}{c}3,365^{* *} \\
{[2,5]}\end{array}$ & 1,349 & 3,471 & 4,6824 & 5,1463 & 1,4827 \\
\hline Paraguai & $\begin{array}{l}1960- \\
2011\end{array}$ & $\begin{array}{c}2,0107^{*} \\
{[6,7]}\end{array}$ & $\begin{array}{c}1,6408^{*} \\
{[13,5]}\end{array}$ & 1,2254 & 3,471 & 4,2535 & 4,2231 & 1,2167 \\
\hline Peru & $\begin{array}{l}1960- \\
2011\end{array}$ & $\begin{array}{c}0,8545^{*} \\
{[5,7]}\end{array}$ & $\begin{array}{c}0,7602^{*} \\
{[5,55]}\end{array}$ & 1,124 & 3,471 & 3,9016 & 3,5285 & 1,0166 \\
\hline
\end{tabular}

Source: the authors. Notes: ${ }^{*}$ Significant at 1\%; ${ }^{*}$ Significant at $5 \%$; In bold: VEC; Standard deviation between brackets.

The coefficients shown in table 1 have the expected signs. They are, furthermore, significant for all countries, both for exports and imports, at $1 \%$ and $5 \%$. Finally, they reveal that the balance of payments equilibrium growth rate (BPEGR) is close to the actual growth rate of the countries. This is the first evidence in favour of Thirlwall's Law.

\subsection{Identifying the instrumental variables}

The aim of this section is to present the econometric method used to test the hypothesis that the ratio of elasticities is endogenous, as well as the instrumental variables used. When we assume that variables are endogenous, in panel or in cross-section data, we use instrumental variables. The statistical test used for this hypothesis is the Durbin-Wu-Hausman (DWH) test, as well as the 
traditional Hausman test, which allows for testing whether the regressor is endogenous. ${ }^{3}$

The Durbin-Wu-Hausman ${ }^{4}(\mathrm{DWH})$ test is a more robust version of the Hausman test, for it uses the device of augmented regressors (Davidson, 2000).

\subsubsection{The share of high technology manufactures in foreign trade}

We chose this variable based on the work of Araújo and Lima (2007). The authors developed a model including various sectors, leading to what they call the Multi-Sectoral Thirlwall's Law (MSTL). It is derived from a Pasinettian framework. The results show that the per capita growth rate of a country is directly related to that of its exports (or the sectoral income elasticities multiplied by the growth rate of the world economy) and inversely related to the sectoral income elasticities of the demand for imports. It should further be noted that the sectoral income elasticities of the demand for exports and imports are weighed by coefficients that measure the participation of each sector in, respectively, total exports and imports.

The major consequence of this model is that changes in the sectoral composition of the economy's output (i.e., in the structure of production) impact its growth rate. Romero et al. (2011) estimated sectoral elasticities for Brazil, obtaining results that corroborate the multi-sector version of Thirlwall's Law. Thus, changes in the sectoral composition of output are reflected in aggregate income elasticities. Similarly, Araújo and Lima (2007) estimated MSTL elasticities for a number of Latin American and Asian countries. They verified that more technology-intensive sectors have higher income elasticities, and that these differences are greater for exports than for imports.

These evidences show that, as industrialization deepens - and, most importantly, as the share of technology-intensive sectors in the economy increases -, the elasticities of exports and imports also vary. This impacts the growth rate of output. Indeed, by making the productive structure of a country dynamic, one allows for the cumulativeness of short-term effects on the economy - which can lead to changes in the long-term patterns of the same country.

Here we therefore assume that the share of high-technology manufactures has a direct impact on the income elasticities. The reason for this is that, according

\footnotetext{
${ }^{3}$ For further information on the instrumental variables model, see Cameron and Trivedi (2009).

${ }^{4}$ The Durbin-Wu-Hausman test is implemented in Stata 11 by the command estat endogenous.
} 
to MSTL and the empirical literature (see Romero et al., 2011; Gouvea and Lima, 2010; Araújo and Lima, 2007), the greater the share of high technology manufactures in the economy, the greater will be the income elasticity of the demand for exports (which relaxes the balance of payments constraint, increasing the ratio of the elasticities). Hence, the faster will also be economic growth.

According to the same hypothesis, the impact of the share of high technology manufactures on economic growth is indirect, i.e, via the income elasticities. This can work as a powerful instrument for testing the endogeneity of the elasticities. We used the classification criterion Lall (2001) proposes for differentiating the technological content of economic sectors, grouping the medium and high technology manufactures into a single sector based on the average 20042010 value.

\subsubsection{The Level of real exchange rate}

The use of the level of the real exchange rate as an instrument for the ratio of the elasticities stems from the theory on the Balassa-Samuelson effect and the evidences Rodrik (2008) and Sampaio and Gala (2008) find, as well as from discussions present in Ferrari et al. (2010), Silveira (2011) and Missio and Jayme Jr. (2012). According to Rodrik (2008) and Sampaio and Gala (2008), exchange rates deviations, calculated by the Balassa-Samuelson effect, are significant in explaining economic growth.

Assuming that the Balassa-Samuelson effect is valid, and, even more, taking the level of the real exchange rate as an instrument for the ratio of the income elasticities, it can be said that the real exchange rate somehow controls for the productivity of the economy. Therefore, it has an indirect influence on economic growth through the ratio of the elasticities. In other words, the real exchange rate (and productivity) alters the ratio of the elasticities, consequently affecting economic growth ${ }^{5}$.

Other works also start with the same hypothesis that the real exchange rate and the ratio of elasticities are related - as the works of Silveira (2011), Missio and Jayme Jr. (2012) and Ferrari et al. (2010) show, the exchange rate has an impact on the income elasticities. That is to say, the exchange rate might affect the income elasticities of the demand for exports and imports, either relaxing or tightening the

\footnotetext{
${ }^{5}$ For the theoretical discussion on the Balassa-Samuelson effect, see Balassa $(1963,1964)$ and Samuelson (1964).
} 
balance of payments constraint on growth, according to Thrilwall's equilibrium equation.

Ferrari et al. (2010) investigate the basic hypothesis that managing the real exchange rate can lead to effects that transcend short-term aggregate demand adjustments. It can actually shift the elasticities, and hence alter the long-term relation between the growth rates of domestic and world output ${ }^{6}$.

As Silveira (2011) points out, we can conclude that McCombie and Roberts (2002) suppose that the real exchange rate has an indirect, long-term effect on the economy's total output. The reason for this is that the exchange rate affects the short-term growth of output (even assuming PPP), thus also transforming the economy's structure of production and, hence, the income elasticities.

Inasmuch as the exchange rate is an essential determinant of the relative prices of the economy, its variations alter the incentives for producing numerous goods. These changes foster or disarticulate various sectors and productive chains. This discussion is not exclusively related to the distribution of incentives between tradable and non-tradable sectors (Rodrik, 2008), but also, and most importantly, to incentives within tradable sectors themselves. According to the theoretical argument advanced here, the proper management of the exchange rate can redirect income to less traditional (and more transversal) sectors, thereby allowing them to develop. As a devalued exchange rate makes the prices of non-traditional sectors competitive in the international and domestic markets, these sectors get a (unique) chance of developing themselves (as an outcome of dynamic economies of scale, learning-by-doing etc.) and boosting their price - and even their non-pricecompetitiveness (considering that qualitative gains can be achieved via the same incentives) (Silveira, 2011).

Finally, the aforementioned work of Missio and Jayme Jr. (2012) explores the possibility of a relationship between the exchange rate, structural heterogeneity, and the income elasticities of the demand for exports and imports in developing economies. The authors provide evidence that an undervalued exchange rate induces a diversification of investments and products in sectors that operate in the world market.

\footnotetext{
${ }^{6}$ It is worth mentioning that, in Krugman's model (1989), the expansion of the labour force determines output growth. A rapid rise in the latter would, in turn, lead to fast-growing exports. In other words, the income elasticities become endogenous due to supply-side variables.
} 


\subsection{Using instruments to test the endogeneity of elasticities}

According to Cameron and Trivedi (2009), the validity of an instrument cannot be tested in a just-identified model. But it is possible to test the validity of overidentifying instruments in an overidentified model, provided the parameters of the model are estimated using optimal $\mathrm{GMM}^{7}$.

The starting point is the fitted value of the criterion function after optimal $\mathrm{GMM}^{8}$, i.e., $Q(\hat{\beta})=\left\{(1 / N)(y-X \hat{\beta})^{\prime} Z\right\} \hat{S}^{-1}\left\{(1 / N) Z^{\prime}(y-X \hat{\beta})\right\}$. If the population moment conditions $E\left\{Z^{\prime}(y-X \beta)\right\}=0$ are correct, then $Z^{\prime}(y-X \hat{\beta}) \simeq 0$, so $Q(\hat{\beta})$ should be close to zero. Under the null hypothesis that all instruments are valid, it can be shown that $Q(\hat{\beta})$ has an asymptotic chi-squared distribution with degrees of freedom equal to the number of overidentifying restrictions.

Large values of $Q(\hat{\beta})$ lead to rejection of $H 0: E\left\{Z^{\prime}(y-X \beta)\right\}=0$. Rejection is interpreted as indicating that at least one of the instruments is not valid. Tests can have power in other directions, however. It is possible that rejection of $H 0$ indicates that the model $X \beta$ for the conditional mean is misspecified. Going the other way, the test is only one of validity of the overidentifying instruments, so failure to reject $H 0$ does not guarantee that all the instruments are valid. This once again highlights the importance of the theoretical argumentation underpinning instruments employed.

\subsubsection{IV estimation and the endogeneity test: an overidentified model}

The fundamental hypothesis for the consistency of the OLS estimator is that the error term is not correlated to the regressor, i.e., $E(u \mid X)=0$. If this hypothesis does not hold, then the OLS estimator cannot be interpreted as a causal effect.

For the matter at hand, the exogeneity hypothesis, a usual assumption for testing Thirlwall's Law, is an indispensable element to find the balance of payments equilibrium growth rate. If the hypothesis is violated, as amongst others McCombie and Roberts (2002) and Missio and Jayme Jr. (2012) suggest, then Thirwall's equilibrium might not be valid - or it might still be valid, but express a bi-directional relationship between the equilibrium growth rate (which reflects the

\footnotetext{
${ }^{7}$ The tests were run in Stata 11, using the estat overid command after IV regression.

${ }^{8}$ The GMM estimator is $\hat{\beta}_{G M M}=\left(X^{\prime} Z W Z^{\prime} X\right)^{-1} X^{\prime} Z W Z^{\prime} y$, where $W$ is any full-rank symmetricweighing matrix.
} 
ratio of the elasticities) and actual growth. In other words, if the ratio of the elasticities is exogenous (structural), Thirlwall's (1979) simplest model holds. More sophisticated versions of the model are more appropriate, such as MSTL or a model that includes the level of the real exchange rate as a subsidiary element in balance of payments constrained growth. This is why we test whether the ratio of the elasticities is endogenous, employing the Durbin-Wu-Hausman (DWH) test, as explained above.

The DWH test initially considers that the ratio of the elasticities $(\varepsilon / \pi)$ "variable" is endogenous. It then tests its endogeneity by means of an instrumental variables model. It is worth mentioning that the endogeneity hypothesis imposed on the ratio of the elasticities will "only" be made to perform the DWH test.

The first stage presents the test of the instruments against the "potentially" endogenous variable. It is thus defined

$$
\left(\frac{\varepsilon}{\pi}\right)_{i}=\beta_{\text {man. }} M_{i}+\beta_{C R} C R_{i}+u_{i}
$$

where $\varepsilon / \pi$ is the ratio of the income elasticities, $M$ is the share of hightechnology manufactured goods in total exports and $C R$ is the level of the real exchange rate.

Equation (11) defines an overidentified model with two instruments, namely, the share of high technology manufactured goods and the level of the real exchange rate. The advantage of an overidentified model is that it allows for testing overidentifying restrictions, whereby one can test the validity of overidentified instruments via a GMM estimation of the parameters.

The endogeneity test for the ratio of the elasticities is made on the structural equation (10), which has already been defined

$$
\left(\frac{y}{z}\right)_{i}=\beta\left(\frac{\varepsilon_{i}}{\pi_{i}}\right)+u_{i}
$$

We opted for a model without the constant term, for if we include the latter it would no longer be a test for Thirlwall's Law. According to Cameron and Trivedi (2009), when there are more instruments than regressors (an overidentified scenario) the most efficient estimators are the 2SLS and GMM.

However, in an overidentified model, 2SLS and GMM estimators can lead to different results. The 2SLS estimator is more efficient if the errors $u_{i}$ are 
independent and homoskedastic. We first present, nevertheless, the results for the first stage of the estimation, which only make sense for a model estimated by 2SLS. The GMM estimator has the same result for the first stage.

The first stage indicates that the instruments are significant in determining the endogeneity of the tested variable. Specifically, both the "share of hightechnology manufactured goods" and the "real exchange rate" are significant at $1 \%$ in determining the ratio of the income elasticities of the demand for exports and imports.

Table 2. First stage regression (Equation 11)

\begin{tabular}{|c|c|c|c|}
\hline Estimator & $\begin{array}{l}\text { Standard-errors } \\
\text { adjustment }\end{array}$ & $\begin{array}{c}\left(\boldsymbol{\beta}_{\text {man. }}\right) \text { estimator: share } \\
\text { of manufactured goods } \\
\text { [t-statistic] } \\
\{\text { p-value }\}\end{array}$ & $\begin{array}{l}\left(\boldsymbol{\beta}_{C R}\right) \text { estimator: } \\
\text { real exchange rate } \\
\text { [t-statistic }] \\
\{p \text {-value }\}\end{array}$ \\
\hline \multirow{2}{*}{ 2SLS } & VCE (Robust) & $\begin{array}{c}2,0082^{*} \\
{[6,49]} \\
\{0,00\}\end{array}$ & $\begin{array}{c}0,1749^{*} \\
{[8,84]} \\
\{0,00\}\end{array}$ \\
\hline & No adjustments & $\begin{array}{c}2,0082^{*} \\
{[7,14]} \\
\{0,00\}\end{array}$ & $\begin{array}{c}0,1749^{*} \\
{[5,68]} \\
\{0,00\}\end{array}$ \\
\hline
\end{tabular}

Source: the authors. Note: ${ }^{*}$ Significant at $1 \%{ }^{* *}$ Significant at $5 \%$.

The validity of the instruments always demands a more careful analysis. Due to this, in addition to the theoretical discussion presented in the former sections, we chose to perform an overidentifying restrictions test. Besides the latter test, table 3 also presents the results of the structural equation for an overidentified model with two instruments, as indicated in equation (10).

Table 3. Overidentified models: test of Equation 10

\begin{tabular}{|c|c|c|c|c|c|}
\hline \multirow[b]{2}{*}{ Estimator } & \multirow{2}{*}{$\begin{array}{l}\text { Standard- } \\
\text { errors } \\
\text { adjustment }\end{array}$} & \multirow{2}{*}{$\begin{array}{l}\left(\boldsymbol{\beta}_{\varepsilon / \pi}\right) \\
\text { estimator: ratio } \\
\text { of the elastic. } \\
\text { [Z-statistic] } \\
\text { \{p-value }\end{array}$} & \multicolumn{2}{|c|}{$\begin{array}{c}\text { Overidentifying restrictions test: } \\
\text { Hansen-Sargan test }\end{array}$} & \multirow{2}{*}{$\begin{array}{c}\text { Wald test } \\
\text { (restriction): } \\
\boldsymbol{H 0 :} \boldsymbol{\beta}_{\varepsilon / \boldsymbol{\pi}}=\mathbf{1} \\
\text { Chi2 statistic } \\
\text { \{p-value }\end{array}$} \\
\hline & & & $\begin{array}{c}\text { Score Chi2 } \\
\{p \text {-value }\}\end{array}$ & $\begin{array}{l}\text { Hansen's J Chi2 } \\
\quad\{p \text {-value }\}\end{array}$ & \\
\hline \multirow{2}{*}{ 2SLS } & $\begin{array}{c}\text { VCE } \\
\text { (Robust) }\end{array}$ & $\begin{array}{c}0,9516^{*} \\
{[35,47]} \\
\{0,00\} \\
\end{array}$ & $\begin{array}{l}0,03558 \\
\{0,8504\}\end{array}$ & & $\begin{array}{c}3,25 \\
\{0,0712\}\end{array}$ \\
\hline & $\begin{array}{l}\text { No } \\
\text { adjustments }\end{array}$ & $\begin{array}{c}0,9516^{*} \\
{[39,37]} \\
\{0,00\} \\
\end{array}$ & $\begin{array}{c}0,0238 \\
\{0,8774\}\end{array}$ & $\begin{array}{l}0,02257 \\
\{0,8806\}\end{array}$ & $\begin{array}{c}4,01^{* *} \\
\{0,0452\}\end{array}$ \\
\hline GMM & $\begin{array}{l}\text { WMATRIX } \\
\text { (Robust) }\end{array}$ & $\begin{array}{c}0,9528^{*} \\
{[36,52]} \\
\{0,00\}\end{array}$ & & $\begin{array}{l}0,03558 \\
\{0,8504\}\end{array}$ & $\begin{array}{c}3,27 \\
\{0,0707\}\end{array}$ \\
\hline
\end{tabular}

Source: the authors. Note: ${ }^{*}$ Significant at $1 \%{ }^{* *}$ Significant at $5 \%$; 
The results indicate that the ratio of the elasticities is significant in determining the growth rate. Besides, the Wald test on restrictions rejects the null hypothesis that the estimator of the ratio of the elasticities is equal to unity. It does so at a $10 \%$ significance level for the models with adjusted residuals and at $5 \%$ for the model with unadjusted residuals, against Thirlwall's (1979) simplest model. This result reveals that there might be other determinants in the canonical model such as the possibility of capital flows, as Thirlwall and Hussein (1982) have already suggested - or the other factors herein discussed.

The results of the overidentifying restrictions test do not reject the null hypothesis that all instruments are valid, given that $p>0,10$ for all identified models: 2SLS (with and without adjusted residuals) and GMM.

In all effect, it was not possible to reject the hypothesis that the share of high technology manufactured goods and the real exchange rate are valid instruments for the ratio of the income elasticities. Nevertheless, and once more, it is important to test for endogeneity, so that the results above (Wald test on restrictions and overidentification) can be more judiciously analysed.

Table 4. Endogeneity: robust Durbin-Wu-Hausman test

\begin{tabular}{|c|c|c|c|c|}
\hline $\begin{array}{l}\mathrm{H} 0=\text { the } \\
\text { variables are } \\
\text { exogenous }\end{array}$ & $\begin{array}{l}\text { Standard- } \\
\text { errors } \\
\text { adjustment }\end{array}$ & $\begin{array}{c}\text { Robust Score } \\
\text { Chi2 } \\
\text { \{p-value }\}\end{array}$ & $\begin{array}{c}\text { Robust Regression } \\
\text { F } \\
\{p \text {-value }\}\end{array}$ & $\begin{array}{c}\text { GMM C Statistic } \\
\text { Chi2 } \\
\{p-\text {-value }\}\end{array}$ \\
\hline \multirow{2}{*}{ 2SLS } & VCE (Robust) & $\begin{array}{l}1,32096 \\
\{0,2504\}\end{array}$ & $\begin{array}{c}1,4072 \\
\{0,2433\}\end{array}$ & \\
\hline & $\begin{array}{c}\text { No } \\
\text { adjustments }\end{array}$ & $\begin{array}{c}1,4425 \\
\{0,2297\}\end{array}$ & $\begin{array}{c}1,4205 \\
\{0,2411\}\end{array}$ & \\
\hline GMM & $\begin{array}{l}\text { WMATRIX } \\
\text { (Robust) }\end{array}$ & & & $\begin{array}{c}1,3054 \\
\{0,2532\}\end{array}$ \\
\hline
\end{tabular}

Source: the authors. Note: *Significant at $1 \%{ }^{* *}$ Significant at $5 \%$;

The test indicates that, for an overidentified model with two instruments (the share of high-technology manufactured goods and the real exchange rate), the hypothesis that the ratio of the elasticities is an exogenous determinant of relative growth cannot be rejected. This is another empirical evidence in favour of Thirlwall's Law. Likewise, the level of the real exchange rate is a subsidiary element of growth, particularly as it affects non-price competitiveness. 


\section{Conclusions}

This paper finds evidence that the level of the real exchange rate is a significant and important determinant of the trade income elasticities. This holds in spite of the fact that the endogeneity tests indicated that the hypothesis of endogenous elasticities is not valid.

Indeed, the level of the real exchange rate affects the ratio of the elasticities by increasing the gains from the sale of tradable goods, profit margins and investment, thus leading to the diversification of the investments and products of sectors that operate in the world market ${ }^{9}$. A managed exchange rate relaxes the constraint and maintains the balance of payments in equilibrium, as it increases the economy's competitiveness (assuming that the income elasticity of the demand for exports of primary goods is low and that the income elasticity of the demand for imports of manufactures is high). Not only so, it also spurs technological development, in light of its benefits to funding and credit, thus stimulating research and innovation. Consequently, the level of exchange rate can affect the supply-side of the economy in the long-term. This theoretical framework leads to the understanding that the income elasticities of the demand for exports and imports are influenced by the real exchange rate, inasmuch as they depend on technological development and the diversification of production.

Indeed, technological progress in developing countries depends on companies having available funds. In this regard, exchange rate devaluations, as they redistribute income from wages to profits, provide companies with access to larger sums of resources to engage in innovative activities. Therefore, the empirical evidence and the theoretical discussion we present endorse the fact that the level of the real exchange rate plays a subsidiary role in the long-term growth of the economies, particularly developing ones. It should be noted, however, that this is a result of higher ratio of income elasticities, which in turn relax the balance of payments constraint and spur economic growth, and not of a price competitiveness-induced improvement in trade.

Regarding the endogeneity of the elasticities, the results do not reject the hypothesis that the ratio of the elasticities is exogenous. They therefore support Thirwall's model, and not Krugman's 45-degree rule (Krugman, 1989). The

\footnotetext{
${ }^{9}$ This condition depends, however, on the economy's growth regime: it cannot apply to wage-led growth. On this topic, see Missio and Jayme Jr. (2012).
} 
restrictions test for the validity of Thirwall's Law implies, however, that the author's canonical model is not sufficient to explain the growth of the analysed countries. As previously mentioned, this suggests that other variables, such as capital flows and foreign debt, should also be taken into consideration when studying growth. The literature has already identified and tested models for these variables: namely, Thirwall and Hussain (1982) proposed the theoretical model that acknowledges the importance of capital flows in balance of payments constrained growth, and Moreno-Brid (1999) proposed the model that includes a sustainable debt constraint. Future research can include capital flows in the equation, so it can be possible to analyse the relationship among this variable, trade income elasticities, the level of exchange rate, and multi-sectoral Thirlwall's law.

Finally, the role of the level of the real exchange rate cannot be neglected when analysing demand-led growth in balance of payments constrained growth models, particularly in light of its stimulus to more productive and technologyintensive sectors. In other words, the real exchange rate is one of the determinants of income elasticity.

\section{References}

Araujo, R. A., \& Lima, G. T. (2007). A structural economic dynamics approach to balance-of-payments-constrained growth. Cambridge Journal of Economics, 31(5), 755-774. https://doi.org/10.1093/cje/bem006

Balassa, B. (1963). An Empirical Demonstration of Classical Comparative Cost Theory. The Review of Economics and Statistics, 45(3), 231. https://doi.org/10.2307/1923892

Balassa, B. (1964). The Purchasing-Power Parity Doctrine: A Reappraisal. Journal of Political Economy, 72(6), 584-596. https://doi.org/10.1086/258965

Blecker, R. A. (2016). The debate over 'Thirlwall's law': balance-of-paymentsconstrained growth reconsidered. European Journal of Economics and Economic Policies: Intervention, 13(3), 275-290. https://doi.org/10.4337/ejeep.2016.03.03

Blecker, R. A., \& Razmi, A. (2007). The fallacy of composition and contractionary devaluations: output effects of real exchange rate shocks in semiindustrialised countries. Cambridge Journal of Economics, 32(1), 83-109. https://doi.org/10.1093/cje/bem021 
Cameron, A. C., \& Trivedi, P. K. (2009). Microeconometrics Using Stata. Texas: Stata Press.

Carvalho, V. R. S. (2007). A restrição externa e a perda de dinamismo da economia brasileira: investigando as relaçóes entre estrutura produtiva e crescimento econômico. Mphil Dissertation, FEA/USP.

Cortes, P. H. C., \& Bosch, J. R. (2015). La Ley de Thirlwall: una lectura crítica. Investigación Económica, 74(292), 11-40.

Davidson, J. (2000). Econometric Theory. Oxford: Wiley-Blackwell.

Ferrari, M., Freitas, F., \& Barbosa Filho, N. (2010). Papel da Taxa de Câmbio Real nos Modelos de Restrição Externa: Uma proposta de releitura com elasticidades endógenas. In Proceedings of the III International Conference of the Associação Keynesiana Brasileira (pp. 1-25). São Paulo: Associação Keynesiana Brasileira.

Gala, P. (2007). Real exchange rate levels and economic development: theoretical analysis and econometric evidence. Cambridge Journal of Economics, 32(2), 273-288. https://doi.org/10.1093/cje/bem042

Gouvea, R. R., \& Lima, G. T. (2010). Structural change, balance-of-payments constraint, and economic growth: evidence from the multisectoral Thirlwall's law. Journal of Post Keynesian Economics, 33(1), 169-204. https://doi.org/10.2753/PKE0160-3477330109

Kaldor, N. (1989). Causes of the slow rate of economic growth in the United Kingdom. In F. Targetti \& A. Thirlwall (Eds.), The Essential Kaldor (p. 560). New York: Holmes \& Meier Publishers.

Krugman, P. (1989). Differences in income elasticities and trends in real exchange rates. European Economic Review, 33(5), 1031-1046. https://doi.org/10.1016/0014-2921(89)90013-5

Lall, S. (2001). Competitiveness, technology and skills. Cheltenham: Edward Elgar. Mccombie, J. (2011). Criticisms and defences of the balance-of-payments constrained growth model: some old, some new. PSL Quarterly Review, 64(259), 353-92. 
McCombie, J., \& Thirlwall, A. (1994). Economic Growth and the Balance-ofPayments Constraint. London: The MacMillan Press LTD. https://doi.org/10.1007/978-1-349-23121-8

Mccombie, J., \& Roberts, M. (2002). The role of the balance of payments in economic growth. In M. Setterfield (Ed.), The Economics of Demand LedGrowth:: Challenging the Supply-side Vision of the Long Run (p. 320). Aldershot: Edward Elgar.

McCombie, J., Pugno, M., \& Soro, B. (2002). Productivity growth and economic performance: essays on Verdoorn's Law. (J. McCombie, M. Pugno, \& B. Soro, Eds.). Basingstoke: Palgrave Macmillan UK. https://doi.org/10.1057/9780230504233

Missio, F. J., \& Jayme, F. G. (2012). Structural Heterogeneity and Endogeneity of Elasticities on the Balance of Payments Constrained Growth Model. In P. Souziakis E.; Cerqueira (Ed.), Models of Balance of Payments Constrained Growth (pp. 239-267). London: Palgrave Macmillan UK. https://doi.org/10.1057/9781137023957_10

Missio, F., Araujo, R. A., \& Jayme, F. G. (2017). Endogenous elasticities and the impact of the real exchange rate on structural economic dynamics. Structural Change and Economic Dynamics, 42, 67-75. https://doi.org/10.1016/j.strueco.2017.06.002

Moreno-Brid, J. C. (1999). Mexico's Economic Growth and the Balance of Payments Constraint: A cointegration analysis. International Review of Applied Economics, 13(2), 149-159. https://doi.org/10.1080/026921799101634

Myrdal, G. (1957). Economic theory and underdeveloped regions. London: Gerald Duckworth \& Co Ltd.

Rapetti, M., Skott, P., \& Razmi, A. (2012). The real exchange rate and economic growth: are developing countries different? International Review of Applied Economics, 266), 735-753. https://doi.org/10.1080/02692171.2012.686483

Rodrik, D. (2008). The Real Exchange Rate and Economic Growth. Brookings Papers on Economic Activity, 2(Fall), 365-412. Retrieved from 
https://www.brookings.edu/wp-content/uploads/2008/09/2008b_bpea_ rodrik.pdf

Romero, J., Silveira, F., \& Jayme Jr., F. (2011) Structural Change and Balance of Payments Constrained Growth: Theory and Brazilian Case. Cepal Review, 4, 173-95.

Sampaio, D., \& Gala, P. (2008). Desequilíbrio Cambial e Crescimento Econômico - Uma análise empírica baseada no modelo Balassa-Samuelson. In Encontro Nacional de Economia da ANPEC (pp. 1-17). Retrieved from http://www.anpec.org.br/encontro2008/artigos/200807211237190-.pdf

Samuelson, P. (1964). Theoretical Notes on Trade Problems. The Review of Economics and Statistics, 46(2), 145. https://doi.org/10.2307/1928178

Silveira, F. (2011). Taxa de Câmbio e Mudança Estrutural: Teoria e Evidência. Mphil Dissertation, Cedeplar/Universidade Federal de Minas Gerais. Retrieved from https://repositorio.ufmg.br/bitstream/1843/AMSA-94OFZE/1/ fabricio_silveira_30_08_2011.pdf

Thirlwall, A. P. (1979). Balance of Payments Constraint as an Explanation of International Growth Rate Differences. Banca Nazionale Del Lavoro Quarterly Review, 32(128), 45-53.

Thirlwall, A. P. (2002). The Nature of Economic Growth: An Alternative Framework for Understanding the Performance of Nations. Cheltenham: Edward Elgar Publishing. Retrieved from https://kar.kent.ac.uk/5439/

Thirlwall, A. P., \& Hussain, M. N. (1982). The Balance of Payments Constraint, Capital Flows and Growth Rate Differences Between Developing Countries. Oxford Economic Papers, 34(3), 498-510. https://doi.org/10.1093/oxfordjournals.oep.a041565

\section{Appendix: Countries of the sample}

We follow Blecker and Razmi (2007) to select the countries used in this study. The authors restricted their sample to developing countries, in which the export of manufactured goods could have a large influence on their aggregate growth. 
The first group of countries to be considered are the largest developing countries whose exports consists of at least $70 \%$ of manufactured products. This is because the manufactured goods, by hypothesis, have a higher possibility of differentiation that commodities and primary products. This share corresponds to the average of $68 \%$ of manufactured exports during the period 1999-2003 reported by UNCTAD (2005). Using this methodology as a reference (share of $70 \%$ ), countries that meet this criterion were updated considering its export in the last year available. The 18 developing countries that meet the Blecker and Razmi (2007)'s paper were: Bangladesh, China, South Korea, Philippines, Hong Kong, India, Jamaica, Malaysia, Mauritius, Mexico, Pakistan, Dominican Republic, Singapore, Sri Lanka, Taiwan, Thailand, Tunisia and Turkey.

These countries were submitted to the discretion of technological classification of Lall (2001). For the purposes of this work, it is expected that if the sum of the ratings RN, LV, MV and HV is above 70 percent, they are manufactured. Only Jamaica does not meet the criteria and is therefore excluded from the test. Besides Jamaica, Taiwan and Bangladesh do not have enough data, which also justified the exclusion of these countries.

Besides, according to Blecker and Razmi (2007), we considered in this study a sample of industrialized countries consisting of nine of the ten largest importers of manufactured goods from developing nations. United States are excluded from the sample because they are used as a reference for all other countries. Furthermore, Australia is included in this sample. Thus, the countries are Australia, Belgium, Canada, France, Holland, England, Italy, Japan and Switzerland.

Finally, although a sample of countries whose exports manufactured goods is less than $70 \%$ are included. These countries were selected according to data availability (for Russia, for example, there is not sufficient data) and because of the importance of the country in international trade The group of developing countries with export basket is less than 70 percent manufactured chosen for the study are: South Africa, Argentina, Brazil, Cameroon, Chile, Colombia, Côte d'Ivoire, Ecuador, Indonesia, Paraguay, Peru Syria and Uruguay. 
Table A - Manufactures Exports (\% total)

\begin{tabular}{|c|c|c|c|c|c|c|c|}
\hline Countries & Year & $\mathbf{P P}$ & MRN & MBT & MMT & MAT & Others \\
\hline \multicolumn{8}{|c|}{ Developing Countries } \\
\hline \multicolumn{8}{|c|}{ Manufacturies $>=70 \%$} \\
\hline China & 2011 & 2,29 & 9,67 & 30,32 & 24,45 & 32,80 & 0,47 \\
\hline South Korea & 2011 & 0,75 & 18,26 & 9,12 & 44,54 & 26,51 & 0,82 \\
\hline Filipines & 2011 & 7,85 & 18,26 & 6,12 & 14,50 & 30,89 & 22,38 \\
\hline Hong Kong & 2011 & 1,25 & 7,85 & 18,74 & 17,51 & 48,01 & 6,65 \\
\hline India & 2010 & 12,84 & 38,16 & 20,67 & 18,77 & 7,33 & 2,23 \\
\hline Malaysia & 2011 & 17,17 & 24,28 & 9,51 & 16,03 & 32,23 & 0,79 \\
\hline Mauricio Islands & 2011 & 4,80 & 33,26 & 51,93 & 5,58 & 2,51 & 1,91 \\
\hline Mexico & 2011 & 18,91 & 9,28 & 8,59 & 37,74 & 22,31 & 3,16 \\
\hline Paquistan & 2011 & 18,98 & 11,78 & 59,07 & 9,03 & 1,07 & 0,08 \\
\hline Dominican Republic & 2011 & 10,15 & 25,40 & 34,51 & 24,02 & 5,52 & 0,41 \\
\hline Singapore & 2011 & 0,94 & 27,91 & 5,07 & 19,90 & 37,26 & 8,91 \\
\hline Sri Lanka & 2011 & 24,95 & 18,70 & 47,07 & 5,69 & 1,12 & 2,46 \\
\hline Tayland & 2011 & 12,88 & 23,41 & 11,21 & 29,86 & 18,16 & 4,48 \\
\hline Tunisia & 2010 & 17,02 & 13,13 & 32,88 & 25,65 & 11,21 & 0,11 \\
\hline Turkey & 2011 & 7,76 & 17,80 & 33,69 & 33,61 & 4,23 & 2,91 \\
\hline \multicolumn{8}{|c|}{$\begin{array}{l}\text { Developing Countries: } \\
\text { Manufacturies }<=70 \%\end{array}$} \\
\hline South Africa & 2011 & 29,61 & 29,07 & 4,69 & 25,74 & 2,60 & 8,29 \\
\hline Argentina & 2011 & 45,55 & 20,44 & 3,72 & 22,56 & 2,62 & 5,10 \\
\hline Brazil & 2011 & 48,98 & 19,53 & 5,05 & 18,99 & 4,28 & 3,16 \\
\hline Cameroon & 2010 & 64,21 & 19,07 & 2,18 & 3,26 & 0,50 & 0,77 \\
\hline Chile & 2011 & 35,27 & 54,24 & 2,62 & 5,35 & 0,63 & 1,89 \\
\hline Colombia & 2011 & 64,57 & 14,78 & 5,02 & 8,10 & 2,06 & 5,47 \\
\hline Cote D'Ivoire & 2011 & 65,88 & 20,46 & 2,80 & 4,09 & 1,53 & 5,24 \\
\hline Equador & 2011 & 78,58 & 14,54 & 2,24 & 3,60 & 0,40 & 0,63 \\
\hline Indonesia & 2011 & 45,62 & 25,78 & 11,08 & 11,49 & 4,90 & 1,12 \\
\hline Paraguay & 2011 & 77,58 & 13,31 & 6,23 & 1,67 & 1,07 & 0,14 \\
\hline Peru & 2011 & 47,39 & 22,21 & 5,87 & 2,23 & 0,33 & 21,97 \\
\hline Siria & 2010 & 55,04 & 21,25 & 13,57 & 8,86 & 1,09 & 0,20 \\
\hline Uruguay & 2009 & 57,82 & 19,30 & 11,34 & 7,03 & 2,48 & 2,03 \\
\hline
\end{tabular}

Source: Own authors based on Economic Comission for Latin America and The Caribbean - SIGCI, following Lall (2001) 